IJLR: International Journal of Law Recontruction

Volume 5, Number 2, September 2021

DOI : http://dx.doi.org/10.26532/ijlr.v5i2.17756

\title{
THE LEGAL POSITION OF ISLAMIC BOARDING SCHOOL (PESANTREM) AS A REHABILITATION EFFORT FOR NARCOTICS ABUSE
}

\author{
Andri Winjaya Laksana \\ Universitas Islam Sultan Agung Semarang \\ andriwinjaya@gmail.com
}

\begin{abstract}
Islamic Boarding School or Pesantren is not only a place to teach religion, but also teaches other fields such as agribusiness and even rehabilitation for narcotics addicts. Rehabilitation is a process of integrated treatment activities to free addicts from drug dependence. Pesantren is one of the places that can be used to rehabilitate people who are addicted to drugs by using Islamic values that are usually applied to the students of Islamic boarding schools. This sociolegal research is descriptive in nature, strengthened by analysis of prescriptive interpretation. The results obtained from this study are the position of the Pesantren in the rehabilitation of drug abuse by applying two treatment methods for drug addicts, namely medical treatment and non-medical treatment. The rehabilitation process for narcotics addicts is the first, ablution, the second dzikr, the third five daily prayers in congregation, fourth, fasting on the Monday and Thursday, fifth or the last one is night prayer (Qiyamullail).
\end{abstract}

Keywords: Abuse; Mentality; Narcotics; Pesantren; Rehabilitation.

\section{A. INTRODUCTION}

Pesantren is an Islamic educational institution that has been established for hundreds of years. In this institution, students are taught and educated about religious knowledge and values. In the early stages of education in Pesantren, the focus is solely on teaching religious sciences through classical books or the yellow book. Islamic boarding schools have a fairly large share, especially in the field of education in Indonesia. Islamic boarding schools scattered throughout the country have contributed so much to the formation of the personality of the Indonesian Muslim community. ${ }^{1}$ Furthermore, after the entry of ideas for renewal of Islamic thought to Indonesia, there was also a change in the field of education.

Pesantren, viewed from a historical, sociological and anthropological perspective, this institution should be seen as an alternative educational institution in Indonesia, but the government seems to see one eye with other formal educational institutions. On the one hand, the government recognizes the products or quality of Pesantren graduates, but on the other hand, Pesantren is still not fully recognized as an educational institution. ${ }^{2}$

1 Nilna Azizatus Shofiyyah, Haidir Ali, Nurhayati Sastraatmadja, Model Pondok Pesantren di Era Milenial, Belajea: Jurnal Pendidikan Islam, Vol. 4, No. 1, 2019, page.1-18

2 Imam Syafe'I, Pondok Pesantren: Lembaga Pendidikan Pembentukan Karakter, A/Tadzkiyyah: Jurnal Pendidikan Islam, Vol 8, No 1 2017, page.61-82 
Pesantren education, which was initially only oriented to the deepening of religious knowledge, has begun to include general subjects, which are expected to broaden the thinking horizons of the student (santri). ${ }^{3}$

Pesantren can be divided into two types, namely modern boarding schools and traditional boarding schools. The traditional Pesantren education system is often called the salafi system, which is a system that maintains the teaching of classical Islamic books as the core of education in Pesantren. Modern Pesantren are educational systems that seek to fully integrate traditional systems and formal school systems (such as madrasah). ${ }^{4}$

In reality, it turns out that Pesantren is not only a place to teach religion, but also teaches other fields such as agribusiness and even for healing narcotics addicts. If people in the past thought that Pesantren was a traditional educational institution that was lagging behind in many respects, now that is no longer the case. Now, Pesantren has become a modern educational institution that has a variety of educational programs.

Changes after changes made by Pesantren are essentially a process to adapt to modernity, which even the world of Pesantren cannot refuse. However, Pesantren certainly have intelligent abilities, namely filtering the good ones to use and the bad ones to throw away.

An interesting phenomenon in the world of Pesantren is it's the place which has a role in healing narcotics addicts. Today, there are many Islamic boarding schools that organize this program. In the past, only Suryalaya and Tasikmalaya Islamic boarding schools, led by Abah Anom, developed themselves as Pesantren that accommodate people with drug addiction, now many have followed suit. Communities around Islamic boarding schools often ask for help from religious institutions to cure narcotics addicts. Thus, Pesantren is one part of the community service program for addicts and an important basis for narcotics prevention programs.

Narcotics abuse from after year has increased which ultimately harming the nation's future cadres. One of the efforts made by the government to overcome the dangers of narcotics is through improvements in the regulation in the field of law. Improvement is very necessary because the influence of narcotics is very large on the survival of a nation. For the sake of perfection in the field of law that specifically regulates narcotics, the government promulgates Act No. 35 of 2009 concerning Narcotics to replace the existing legislation that has already existed namely Act No. 22 of 1997 concerning Narcotics. ${ }^{5}$

The misuse of narcotics, in fact, is a criminal act, so that the perpetrator should carry out a legal process like law enforcement in other criminal cases. The misuse of narcotics includes the qualification of a

3 Haidar Putra Daulay, Pendidikan Islam Dalam Sistem Pendidikan Nasional di Indonesia, Kencana, Jakarta, 2004, page. 25

4 Hasbullah, Sejarah Pendidikan Islam di Indonesia: Lintasan Sejarah Pertumbuhan dan Perkembangan, Raja Grafindo Persada, Jakarta, 1999, page. 155.

5 Andri Winjaya Laksana, Social Analysis of Narcotics Abuse Prevention Women, Jurnal Pembaharuan Hukum, Volume VI No.3 September-December 2019, page.308-318 
criminal act (delict) which is regulated in statutory regulations. ${ }^{6}$ Narcotics is not a new problem in Indonesia. The distribution area starts from the city to remote villages. The majority of people have the opinion that most drug users are young people, although anyone can become a drug user. Parents, children, teenagers, seniors, privillage people, homeless people, police, officials do not rule out the possibility of scholars.

Narcotics is a complicated problem for mankind, especially for Indonesia. Drug epidemics usually attack anyone, such as the younger generation who are frustrated, deeply disappointed, looking for fun, seeking peace, and miscommunication starting from the trial and error use of drugs. Without them realizing that when they use drugs, longer then become addicted, addicted and more severe dependence. This must stop immediately, for a better future.

Narcotics addicts who are undergoing a judicial process can be placed in medical rehabilitation and/or social rehabilitation institutions which are the authority of investigators, public prosecutors, or judges in accordance with the level of examination after obtaining a recommendation from a team of doctors. The obligation to undergo medical rehabilitation and/or social rehabilitation also applies to narcotics addicts who are ordered based on a court decision if the narcotics addict is proven guilty of committing a narcotic crime; or a court ruling if the narcotic addict is not proven guilty of committing a narcotic crime.

Rehabilitation is a process of integrated treatment activities to free addicts from drug dependence. The medical rehabilitation process includes assessment, preparation of rehabilitation plans, outpatient or inpatient rehabilitation programs and post-rehabilitation programs. Hospitalization is in accordance with the rehabilitation plan that has been prepared taking into account the results of the assessment which includes medical intervention. Medical interventions include detoxification programs, symptomatic therapy, and/or medical maintenance therapy, as well as treatment of complications. ${ }^{7}$

Provisions for the rehabilitation of addicts and victims of narcotics abuse have indeed been guaranteed in Article 54 of Act No. 35 of 2009 concerning Narcotics and Government Regulation Number 25 of 2011 concerning the Implementation of Obligatory Reporting of Narcotics Addicts, but it does not necessarily mean that narcotics abusers can be placed in rehabilitation homes. Because placement in a rehabilitation center must go through a strict assessment to determine the level of dependence on narcotics abusers. ${ }^{8}$

Based on state law, the prohibition of drug abuse has been regulated, as well as religious law, especially Islam. Islam is a religion based on the power of reason (ratio), a person's religious value is not perfect if the

6 Andri Winjaya Laksana, Sociological Analysis of Narcotics Circulation Treatment on Students, Jurnal Pembaharuan Hukum, Volume 8 No.1 January-April 2021, page.105-117

7 Dadang Hawari, Penyalahgunaan dan Ketergantungan NAZA (Narkoba, Alkohol dan Zat Adiktif), Medical Faculty of Indonesia University, Jakarta, 2006, page.26-28.

8 Arif Efendi, Peran Strategis Lembaga Pendidikan Berbasis Islam di Indonesia, El-Tabarwi Jurnal Pendidikan Islam, Vol 1 No 1 2008, page. 9. 
function of his mind is disturbed. The function of reason in Islam is very important in accepting, analyzing and believing all teachings received through the Qur'an and Sunnah. Therefore, efforts to keep the mind healthy in living life in the world, is an unavoidable necessity to live according to the rules and orders that have been outlined in the Qur'an and Sunnah. ${ }^{9}$

The purpose of this research is to analyze and examine the position of Pesantren in the implementation of rehabilitation for victims of narcotics abuse, so that the results of the effectiveness of rehabilitation carried out by Pesantren in the context of healing for victims of narcotics abuse can be known.

\section{B. REASEARCH METHODS}

This socio-legal research is descriptive in nature, reinforced by prescriptive interpretation analysis, socio-legal research concentrates on real law (law in action). The socio-legal approach adopts qualitative and quantitative methods from various social sciences and sees law as a social phenomenon. The character of its methodological scope is increasingly difficult to define. Socio-legal studies cover a wide range of disciplinary contexts, both in the social and legal sciences, linking law to the sociological, political and economic dimensions of human activity. ${ }^{10}$ In sociolegal research, whose research method is a combination of doctrinal legal research methods and empirical legal research methods (which borrow from social science methods), what the researchers do is document studies, which are accompanied by field studies. ${ }^{11}$

\section{RESULTS AND DISCUSSION}

\section{The Position of Pesantren in Narcotics Abuse Rehabilitation Efforts}

A drug addict is someone whose mental and spiritual condition has been damaged so that it affects the behavior shown, such as: not practicing worship, not being able to interact properly, unable to take care of themselves and their surroundings. Therefore, there is a need for rehabilitation that focuses on improving the soul, especially the mental and spiritual of narcotic addicts.

Religious therapy ( $p$ sychoreligious) plays an important role for drug addicts, both in terms of prevention, therapy and rehabilitation. People who do not have a religious commitment are four times more likely to be involved in drug abuse and dependence. Religion has an important role in the therapy and rehabilitation of drug abusers or dependence. ${ }^{12}$

9 Imam Tabroni, Narkoba Dalam Paradigma Islam, Balai Penerbit Badan Narkotika Provinsi Jawa Timur, Surabaya, 2010, page. 34-35.

10 Muhammad Helmy Hakim, Pergeseran Orientasi Penelitian Hukum: Dari Doktrinal Ke SosioLegal, SYARIAH Jurnal Hukum dan Pemikiran, Volume 16, Nomor 2, December 2016, page. $105-114$

11 Sulistyowati Irianto \& Shidarta (eds), Metode Penelitian Hukum: Konstelasi \& Refleksi, Yayasan Obor Indonesia, Jakarta, 2011, page.12

12 Nur Afni Noviarini, Mahargyantari Purwani Dewi, Hendro Prabowo, Hubungan Antara Dukungan Sosial Dengan Kualitas Hidup Pada Pecandu Narkoba Yang Sedang Menjalani 
Rehabilitation in Pesantren consists of three elements, namely scientific, divine, and natural. This explains that the presence of divine elements in Pesantren is very committed to improving the mental and spiritual mentality of drug addicts with therapeutic methods using a religious approach, namely Islam. In the divine element there are forms of therapy that play a role in optimizing mental spirituality, namely night bath therapy, prayer therapy, dzikr therapy, rukyah therapy, istighotsah therapy, and giving karomah water. That people who do not have a religious commitment will be four times more likely to be involved in drug abuse and dependence. People who use drugs are human beings who are weak in reason and have faith in the rehabilitation center as one of the rehabilitation centers that improve mental and spiritual conditions.

Drug addicts who undergo rehabilitation at Islamic boarding schools have experienced a change in their condition that is better than before after consuming drugs. This indicator is indicated by changes in worship, physical, interaction by drug addicts. There is a change in drug addicts after undergoing rehabilitation, indicating the maximum performance of the rehabilitation center in improving the condition of drug addicts. The results of previous studies also explain the changes in drug addicts after attending spiritual rehabilitation at the As-Stressiyah Islamic Boarding School Darul Ubudiyah Sejati Sejomulyo Juwana Pati. ${ }^{13}$ After a change in drug addicts, it is hoped that they will be able to return to normal functioning in everyday life, both at home, at school, at work, and in their social environment.

The position of Islamic boarding schools in drug abuse rehabilitation efforts applies two treatment methods for drug addicts, namely medical treatment and non-medical treatment. The method applied is in accordance with the rules of Act No. 35 of 2009 in Chapter IX Article 54, that: "Narcotics addicts and victims of narcotics abuse are obliged to undergo medical rehabilitation and social rehabilitation." Efforts to rehabilitate narcotics addicts and victims of narcotics abuse are mandatory and should be prioritized. Once the importance of rehabilitation as an effort to restore the situation should be a special concern in dealing with narcotics crimes, the article, we know here that there are narcotics that contain substances that can make a person dependent, and of course this cannot be resolved only with imprisonment. There needs to be rehabilitation for the perpetrator so that he doesn't repeat his actions again, either intentionally or because of the urge of opium caused by narcotics consumed previously. ${ }^{14}$

Rehabilitasi, Proceeding PESAT (Psikologi, Ekonomi, Sastra, Arsitektur \& Teknik Sipil), Vol. 5 October 2013, page.116-122

13 Fathur Rohman, Pendidikan Spiritual Berbasis Tarekat bagi Pecandu Narkoba (Studi Kasus di Pondok Pesantren As-Stressiyah Darul Ubudiyah Sejati Sejomulyo Juwana Pati), Jurnal Pendidikan Agama Islam (Journal of Islamic Education Studies), Vol. 5 No. 2 2017, page.161-180

14 Andri Winjaya Laksana, Tinjauan Hukum Pemidanaan Terhadap Pelaku Penyalahguna Narkotika Dengan Sistem Rehabilitasi, Jurnal Pembaharuan Hukum, Volume II No. 1 January - April 2015, page.74-85 
Although the Pesantren provides medical treatment, non-medical treatment is prioritized. Medical treatment is applied if a physical illness is found in a drug addict who requires medical treatment.

Rehabilitation for drug addicts has five functions, namely the understanding function, control function, forward analysis function, prevention function, and healing/treatment function. ${ }^{15}$ Pesantren in each activity can be seen that there are functions, namely the function of understanding, control, analysis function, prevention function and healing/treatment function. The function of understanding can be seen from the provision of advice for drug addicts related to worship, good relationships, good behavior and speaking. The control function is seen in therapeutic activities so that drug addicts are in good moral control. The function of future analysis is observed when conducting Islamic guidance and counseling activities. The function of prevention is seen when drug addicts will act to harm themselves and others. The function of healing/treatment can be observed through the process of therapy and control over health and hygiene.

Daru Wijayanti explained several stages of rehabilitation for drug addicts, namely: the stage of medical rehabilitation (detoxification), the stage of non-medical rehabilitation, and the stage of advanced development (after care). ${ }^{16}$ Islamic boarding schools do not prioritize medical treatment unless the patient has serious physical injuries that need medical attention. This explanation is different from the opinion of Daru Wijayanti, namely the stage of medical rehabilitation is the administration of certain drugs to reduce withdrawal symptoms (sakau).

Pesantren has this policy because to avoid the side effects of giving drugs for drug addicts, if the patient is given warm drinking water that has been given the practice of prayer while still being accompanied by officers. The non-medical rehabilitation stage is carried out with various healing therapies, such as prayer, dzikr, living in a community together, skills development. Furthermore, the post-care stage in Islamic boarding schools does not have this stage, because after completing the rehabilitation the patient is the responsibility of the family. The absence of this stage causes the patient to return to the boarding school, usually the families who ask to be picked up are those who have been rehabilitated at this orphanage, but there are also those who are not.

Pesantren is very trying to improve the mental and spiritual condition of drug addicts. Various activities in development, especially those closely related to community development, Pesantren always participate in various development programs such as prevention, eradication, abuse and illicit drug trafficking (P4GN). ${ }^{17}$ These efforts can be seen from the changes in drug addict patients during rehabilitation.

15 Adz-Dzaky Hamdani Bakran, Konseling dan Psikoterapi Islam, Fajar Pustaka Baru, Yogyakarta, 2004, page. 270.

16 Daru Wijayanti, Revolusi Mental Stop Penyalahgunaan Narkoba, Fajar Pustaka Baru, Yogyakarta, 2004, page. 228.

17 Suharsimi Arikunto, Prosedur Penelitian Suatu Pendekatan Praktek, Rineka Cipta, Jakarta, 2006, page. 129. 
Several factors that support the change in drug addicts include: the leadership factor of the Islamic boarding school which brings the rehabilitation center to focus on mental and spiritual improvement, the existence of three elements of healing, namely natural, divine, and scientific, and the assistance of rehabilitation officers. The explanation above can also be concluded that the good mental and spiritual condition of drug addicts cannot survive after leaving the Pesantren, because there is no after-care stage implemented by the Pesantren. In fact, the function of the post-care stage is to monitor the patient's activities after leaving the rehabilitation center.

\section{The Rehabilitation Process at Pesantren in the Efforts of Rehabilitation of Narcotics Abuse}

Islamic religious education for drug addicts is certainly not the same as Islamic religious education in schools in general. The difference is based on different mental state factors. Students in general do not have serious mental problems, but drug addicts have severe mental problems. Basically, Islamic religious education for drug addicts is to raise awareness that what he has done is a sinful act and must be stopped.

Pesantren can become a religion-based social rehabilitation institution for narcotics abusers, where the recovery technique is by prioritizing religious knowledge and instilling in the heart religious values and giving the view that narcotics are illicit goods that should really be shunned. In the view of Islam, narcotics are haraam, which is haraam as khamr is mentioned in the Qur'an. Khamr is an intoxicating liquor and can make people lose their minds when consuming it. Likewise with narcotics whose effects are far more damaging when compared to liquor. Therefore, Islamic boarding schools as the basis of Islamic education that are widely known by the Indonesian people can participate in recovering narcotics addicts. ${ }^{18}$

Islamic boarding schools in seeking rehabilitation for narcotics addicts have the following objectives:

a. First, treating drug addicts so that they are fully recovered and not repeat their actions.

b. Second, getting closer to God, through ritual practices in the healing process of drug addicts.

c. Third, giving enlightenment and awareness to return to the right and straight path (shirathal mustaqiem).

d. Fourth, teach to achieve goodness and safety in the world and the hereafter through the prayer "rabbanaa aatina fidunyaa hasanah wafil akhirooti hasanah waqina adzabannaar."

e. Fifth, instill a strong faith in order to stay away from drugs and all kinds of actions that hurt and damage the soul and body of humans as noble creatures of God.

18 Vivi Ariyanti, Bani Syarif Maula, Rehabilitasi Berbasis Pesantren bagi Penyalah Guna Narkotika sebagai Bentuk Perlindungan Hukum, Komunika: Jurnal Dakwah dan Komunikasi, Vol. 14 No. 2 October 2020, page.259-282 
Narcotics users can only sleep, while restlessness, heart palpitations and blood pressure become normal if they use drugs continuously, which eventually leads to dependence. However, there is a reason why Narcotics are preferred, namely:

a. There is a sense of freshness and enthusiasm,

b. self-confidence increases,

c. Relationships with other people become intimate,

d. Increase imagination

However, the enjoyment obtained is very temporary, so that using drugs does much more harm (damage) than benefits. According to Laurencius Daniel, SKM, using drugs is very dangerous: ${ }^{19}$

a. Disrupt the function of other body organs such as the heart, lungs, liver and reproductive system, so that various diseases can arise.

b. Inhibits the work of the brain, so that consciousness decreases and drowsiness arises.

c. Affects the brain as the control center of the body and affects all body functions. Because it works on the brain, drugs change the mood, way of thinking, awareness and behavior of the wearer.

In addition, narcotics have effects for users, namely:

a. Hallucinogens, a person becomes hallucinated by seeing an object,

b. Stimulants, organs such as the heart and brain work faster than normal.

c. Depressants, can eat the central nervous system and reduce the body's functional activity.

d. Addictive, the user becomes addicted.

e. Organs in the body are damaged, if overdose results in death.

As for how to cure drug addicts carried out in Islamic boarding schools, generally taken from methods such as in Islamic religious rituals in general, namely: ${ }^{20}$

a. First, do the cleansing of the heart that is unjust (dirty), with ablution in order to neutralize the heart that is influenced by the devil. Neutralization is done by means other than ablution such as when going to prayer, also pouring water on drug users.

b. Second, strengthening faith by doing remembrance or multiplying sentences of remembrance. This is done because in essence drug addicts have broken their faith. To repair the damaged faith, faith is grown or faith strengthening is done by multiplying remembrance, namely repeating "Laailaaha Illallah".

c. Third, pray five times. Performing prayers in congregation, in

19 Ali Azhar, KMS. Novyar Satriawan Fikri, Vivi Arfiani Siregar, Mulono Apriyanto, Pencegahan, Pemberantasan, Penyalahgunaan dan Peredaran Gelap Narkoba (P4GN) Pada Pesantren, Jurnal Inovasi Penelitian, Vol.1 No.11 April 2021, page.2463-2468

20 Musfir bin Said Az-Zahrani, Konseling Terapi, Gema Insani, Jakarta, 2005, page.9. 
addition to fulfilling obligations to Allah, is also a way to get closer to the Creator (Kholiq). Someone who falls and becomes a drug addict, must be because he is far from God. It is impossible, if a servant is close to Allah, to become a drug addict, because Allah will take care of the person concerned. The real benefit of being close to Allah, a person will get peace of life, happiness, and safety in this world and the hereafter. The closer to Allah, the closer Allah will be to His servants. His sins are forgiven if he has truly repented of repentance (thaubatan nasuuhah), and will obtain mental and physical health.

d. Fourth, will gain mental and physical health. Fourth, fasting Monday and Thursday. The next stage is to fast like the Prophet Dawud, which is one day of fasting and the next day not fasting (breaking) continuously. The way of medical treatment outside the Pesantren, namely the doctor recommends to drug addicts to eat nutritious food and reduce food. How to reduce eating according to the sunnah of the Prophet Muhammad SAW is fasting Monday and Thursday, and fasting in the style of the Prophet Dawud Alaihissalam.

e. Fifth, evening prayer (Qiyamullail). Evening prayers are also very good to do to get a noble and commendable position in the sight of Allah. Drug addicts, will recover if praying in the middle of the night. When people are sleeping soundly, a servant wakes up and performs ablution and prays Qiyamullail. The command to pray tonight is contained in the Qur'an surah Al Israa verse 79 which means "And on some nights, pray tahajjudlah, may your Lord put you in a commendable place."

Rehabilitation of victims of narcotics abuse is a solution to cure for drug dependence, the implementation of rehabilitation using Sufism in healing. Many religious psychologists refer to human essence as religious instinct, which means religious instinct or religious desire. Meanwhile, in contemporary psychological discourse, human essence is referred to as the God spot as stated by Ramachandran in the book Spiritual Quotient, namely that the term God point describes the existence of something that is original or natural related to divinity in humans. Some of the previous explanations show that spirituality is an awareness that exists in humans, about the presence of God in their lives. To maintain this kind of awareness, it is necessary to foster spiritual health for everyone, especially for people who experience disturbances in life, both physically and psychologically. ${ }^{21}$

\section{CONCLUSION}

The position of Islamic boarding schools in drug abuse rehabilitation efforts applies two treatment methods for drug addicts, namely medical treatment and non-medical treatment. The method applied is in accordance

21 Akmal Hawi, Remaja Pecandu Narkoba: Studi tentang Rehabilitasi Integratif di Panti Rehabilitasi Narkoba Pondok Pesantren Ar-Rahman Palembang, Tadrib, Vol. IV, No.1, June 2018, page.99-119 
with the rules of Act No. 35 of 2009 in Chapter IX Article 54, that: "Narcotics addicts and victims of narcotics abuse are obliged to undergo medical rehabilitation and social rehabilitation." Although the Pesantren provides medical treatment, non-medical treatment is prioritized. Medical treatment is applied if a physical illness is found in a drug addict who requires medical treatment. The process of rehabilitating narcotics addicts is the first, doing the cleansing of the heart that is unjust (dirty), with ablution. Second, strengthening faith by doing remembrance or multiplying sentences of remembrance, namely repeating "Laailaaha Illallah". Third, pray five times in congregation. Fourth, fasting on Mondays and Thursdays, but the next stage is to fast like the Prophet Dawud, namely one day of fasting and the next day not fasting (breaking) continuously. The way of medical treatment outside the Pesantren, namely the doctor recommends to drug addicts to eat nutritious food and reduce food. How to reduce eating according to the sunnah of the Prophet Muhammad SAW is fasting Monday and Thursday, and fasting in the style of the Prophet Dawud. The fifth or last is the night prayer (Qiyamullai).

\section{Books}

\section{BLIBIOGRAPHY}

Adz-Dzaky Hamdani Bakran, 2004, Konseling dan Psikoterapi Islam, Fajar Pustaka Baru, Yogyakarta;

Dadang Hawari, 2006, Penyalahgunaan dan Ketergantungan NAZA (Narkoba, Alkohol dan Zat Adiktif), Medical Faculty of Indonesia University, Jakarta;

Daru Wijayanti, 2004, Revolusi Mental Stop Penyalahgunaan Narkoba, Fajar Pustaka Baru, Yogyakarta;

Haidar Putra Daulay, 2004, Pendidikan Islam Dalam Sistem Pendidikan Nasional di Indonesia, Kencana, Jakarta;

Hasbullah, 1999, Sejarah Pendidikan Islam di Indonesia: Lintasan Sejarah Pertumbuhan dan Perkembangan, Raja Grafindo Persada, Jakarta;

Imam Tabroni, 2010, Narkoba Dalam Paradigma Islam, Balai Penerbit Badan Narkotika Provinsi Jawa Timur, Surabaya;

Musfir bin Said Az-Zahrani, 2005, Konseling Terapi, Gema Insani, Jakarta;

Suharsimi Arikunto, 2006, Prosedur Penelitian Suatu Pendekatan Praktek, Rineka Cipta, Jakarta;

Sulistyowati Irianto \& Shidarta (eds), 2011, Metode Penelitian Hukum: Konstelasi \& Refleksi, Yayasan Obor Indonesia, Jakarta.

\section{Journals}

Akmal Hawi, Remaja Pecandu Narkoba: Studi tentang Rehabilitasi Integratif di Panti Rehabilitasi Narkoba Pondok Pesantren Ar-Rahman Palembang, Tadrib, Vol. IV, No.1, June 2018; 
Ali Azhar, KMS. Novyar Satriawan Fikri, Vivi Arfiani Siregar, Mulono Apriyanto, Pencegahan, Pemberantasan, Penyalahgunaan dan Peredaran Gelap Narkoba (P4GN) Pada Pesantren, Jurnal Inovasi Penelitian, Vol.1 No.11 April 2021;

Andri Winjaya Laksana, Tinjauan Hukum Pemidanaan Terhadap Pelaku Penyalahguna Narkotika Dengan Sistem Rehabilitasi, Jurnal Pembaharuan Hukum, Volume II No. 1 January - April 2015;

Andri Winjaya Laksana, Social Analysis of Narcotics Abuse Prevention Women, Jurnal Pembaharuan Hukum, Volume VI No.3 SeptemberDecember 2019;

Andri Winjaya Laksana, Sociological Analysis of Narcotics Circulation Treatment on Students, Jurnal Pembaharuan Hukum, Volume 8 No.1 January-April 2021;

Arif Efendi, Peran Strategis Lembaga Pendidikan Berbasis Islam di Indonesia, El-Tabarwi Jurnal Pendidikan Islam, Vol 1 No 1 2008;

Fathur Rohman, Pendidikan Spiritual Berbasis Tarekat bagi Pecandu Narkoba (Studi Kasus di Pondok Pesantren As-Stressiyah Darul Ubudiyah Sejati Sejomulyo Juwana Pati), Jurnal Pendidikan Agama Islam (Journal of Islamic Education Studies), Vol. 5 No. 2 2017;

Imam Syafe'I, Pondok Pesantren: Lembaga Pendidikan Pembentukan Karakter, Al-Tadzkiyyah: Jurnal Pendidikan Islam, Vol 8, No 1 2017;

Muhammad Helmy Hakim, Pergeseran Orientasi Penelitian Hukum: Dari Doktrinal Ke Sosio-Legal, SYARIAH Jurnal Hukum dan Pemikiran, Volume 16, Nomor 2, December 2016;

Nilna Azizatus Shofiyyah, Haidir Ali, Nurhayati Sastraatmadja, Model Pondok Pesantren di Era Milenial, Belajea: Jurnal Pendidikan Islam, Vol. 4, No. 1, 2019;

Nur Afni Noviarini, Mahargyantari Purwani Dewi, Hendro Prabowo, Hubungan Antara Dukungan Sosial Dengan Kualitas Hidup Pada Pecandu Narkoba Yang Sedang Menjalani Rehabilitasi, Proceeding PESAT (Psikologi, Ekonomi, Sastra, Arsitektur \& Teknik Sipil), Vol. 5 October 2013;

Vivi Ariyanti, Bani Syarif Maula, Rehabilitasi Berbasis Pesantren bagi Penyalah Guna Narkotika sebagai Bentuk Perlindungan Hukum, Komunika: Jurnal Dakwah dan Komunikasi, Vol. 14 No. 2 October 2020; 